KATARZYNA MAJCHRZAK

Uniwersytet Kardynała Stefana Wyszyńskiego w Warszawie

\title{
ROZBÓJ W ŚWIETLE PRAWA KARNEGO KANONICZNEGO
}

Treść: Wstęp. - 1. Pojęcie przestępstwa rozboju w prawie karnym kanonicznym. - 1.1. Kodeks Prawa Kanonicznego z 1917 r. - 1.2. Kodeks Prawa Kanonicznego z 1983 r. 2. Strona obiektywna przestępstwa rozboju. - 2.1. Kodeks Prawa Kanonicznego z 1917 r. - 2.2. Kodeks Prawa Kanonicznego z 1983 r. - 3. Strona subiektywna przestępstwa rozboju. - 3.1. Kodeks Prawa Kanonicznego z 1917 r. - 3.2. Kodeks Prawa Kanonicznego z 1983 r. - 4. Sankcja karna. - 4.1. Kodeks Prawa Kanonicznego z 1917 r. - 4.1.1. Karalność rozboju dokonanego przez osoby świeckie - 4.1.2. Sankcje karne przeciwko duchownym dopuszczającym się przestępstwa rozboju - 4.2. Kodeks Prawa Kanonicznego z 1983 r. - Wnioski końcowe.

\section{Wstęp}

Przestępstwo rozboju zalicza się do przestępstw forum mieszanego (mixti fori). Oznacza to, że sprawca może być ścigany i karany zarówno przez władzę kościelną, jak i państwową. W związku z tym powstaje pytanie, jakie normy prawne mają być stosowane w sądach kościelnych do sprawcy rozboju, odnośnie do osób duchownych albo świeckich. Mianowicie czy sędzia kościelny winien kierować się wyłącznie zasadami prawa karnego kanonicznego, czy mają tu także zastosowanie przepisy kodeksów karnych państwowych.

Z uwagi na przestrzeganie w sądownictwie kościelnym zasady sprawiedliwości, wyrażonej w powiedzeniu ne bis idem, wchodzi tu w grę zasada prewencji. W wypadku ścigania i karania sprawcy przestępstwa rozboju przez państwo, będą miały zastosowanie przepisy kodeksów karnych państwowych. W myśl kan. 2198, kan. 1933 §3 i kan. 2223 §3 n. 2 KPK/1917 oraz kan. 1344 n. 2 KPK/1983, wymiar kary przez państwo, osobom świeckim, uznaje się z punktu widzenia 
prawa kościelnego za spełniający wymogi prawa naturalnego, co do odpowiedzialności karnej za winę.

Należy zaznaczyć, iż prawodawca kościelny w obowiązującym KPK/1983 wprost nie wymienia przestępstwa rozboju, inaczej niż czynił to KPK/1917. Jednak dzięki ogólnej zasadzie wyrażonej w obowiązującym kan. 1399 przestępstwo rozboju nie jest obojętne dla ustawodawcy kościelnego w tym sensie, że całość zagadnienia pozostawia się do rozstrzygnięcia karnemu prawu świeckiemu.

Warto wspomnieć, iż przestępstwo rozboju - jako kradzież przy użyciu siły - znane było już w prawie rzymskim. Czyny przestępne godzące bezpośrednio w interesy osobiste i majątkowe poszczególnych osób traktowane były jako przestępstwa prawa prywatnego - delictum, do których zaliczono przestępstwo rozboju. W okresie końca republiki rzymskiej, z uwagi na niepokoje społeczne, pretor wprowadził specjalną skargę - actio vi bonorum raptorum stosowaną przeciwko temu, kto dokonał kradzieży z zastosowaniem przemocy. W prawie pretorskim rapina jako delikt prywatny przewidywał karę prywatną - in quadruplum, którą sprawca przestępstwa rozboju winien zapłacić pokrzywdzonemu ${ }^{1}$.

\section{Pojęcie przestępstwa rozboju w prawie karnym kanonicznym}

\subsection{Kodeks Prawa Kanonicznego z 1917 r.}

KPK/1917 nie podaje definicji przestępstwa rozboju. Wydawać by się mogło, iż określenie tegoż pojęcia pozostawia się nauce i praktyce procesowej. KPK/1917 posługuje się tylko terminem „rozbój” w kan. 2354, ale nie określa dokładnie znamion ustawowych tego przestępstwa, czyli stosuje dyspozycję nazwową. W nawiązaniu do doktryny, przedkodeksowej kanoniści podają, że przez rozbój rozumie się niesprawiedliwe zabranie cudzej rzeczy dokonane przy użyciu siły².

1 W. WoŁodkiewicz - M. ZabŁocka, Prawo rzymskie. Instytucje, Warszawa 1996, s. $253,262$.

2 F. WeRnZ - P. VIDAL, Ius canonicum, ed. 2, t. VII, Ius poenale ecclesiasticum, Romae 1951, s. 567: ,rapina, quo nomine intelligebatur iniusta ablatio rei alienae per vim facta (...)". 
Prawodawca o rozboju, jako o przestępstwie mówi w kan. 2354 $\S 1 \mathrm{KPK} / 1917^{3}$. Zalicza rozbój do przestępstw mixti fori, w których ściganiu i karaniu zainteresowana jest zarówno władza państwowa, jak i kościelna. Dla zachowania sprawiedliwości, przy wymiarze kar za rozbój prawodawca kościelny przyjmuje zasadę prewencji ${ }^{4}$. Z tej racji, że zasada nie zawsze była przez państwo przestrzegana, można powiedzieć, że KPK/1917 zrezygnował z zasady prewencji na rzecz państwa, gdy sprawcą przestępstwa jest osoba świecka. Nie gasiło to jednak możliwości ukarania sprawcy przez sąd kościelny, czego wyrazem jest norma kan. $1933 \S 3^{5}$, w którym użyte słowo regulariter wskazuje, iż: prawodawca kościelny przyjmuje, że jeśli sprawcą przestępstwa rozboju będzie laik, to Kościół nie powinien wszczynać procesu, a więc karalność należy pozostawić władzy świeckiej.

$\mathrm{Z}$ kanonu tego wynika, że w stosunku do sprawcy rozboju należy stosować państwowe prawo karne, gdyż tylko na podstawie takiego, państwo wymierza karę laikom. Można stąd wnioskować, że w stosunku do sprawcy, którym jest świecki prawodawca kościelny implicite przyjmuje ustawy państwowe. Jest to odmienna forma od kanonizacji prawa państwowego odnośnie zobowiązań, explicite przyjęta w kan. $1529^{6}$. Natomiast w stosunku do duchownych KPK/1917 stoi na stanowisku utrzymania privilegium fori czemu daje wyraz w kan. $120 \S 1^{7}$, a wyraźne potwierdza w kan. 2354. Niemniej i w tym wypadku sędzia

${ }^{3}$ Kan. 2354 §1: „Laicus qui fuerit legitime damnatus ob delictum (...) rapinae (...), ipso iure exclusus habeatur ab actibus legitimis ecclesiasticis et a quolibet munere, si quod in Ecclesia habeat, firmo onere reparandi damna".

${ }^{4}$ Kan. 1553 §2: „In causis in quibus tum Ecclesia tum civilis potestas aeque competentes sunt, quaeque dicuntur mixti fori, est locus praeventioni”.

${ }^{5}$ Kan. 1933 §3: „In delictis mixti fori Ordinarii regulariter ne procedant cum reus laicus est et civilis magistratus, in reum animadvertens, publico bono satis consulit".

${ }^{6}$ Kan. 1529: „Quae ius civile in territorio statuit de contractibus tam in genere, quam in specie, sive nominatis sive innominatis, et de solutionibus, eadem iure canonico in materia ecclesiastica iisdem cum effectibus serventur, nisi iuri divino contraria sint aut aliud iure canonico caveatur".

7 Kan. 120 §1: „Clerici in omnibus causis sive contetiosis sive criminalibus apud iudicem ecclesiasticum conveniri debent, nisi aliter pro locis particularibus legitime provisum fuerit". 
kościelny może posługiwać się państwowym ustawodawstwem karnym, aby uniknąć dwutorowości stosowania przepisów kościelnych i państwowych.

W związku z powyższym pojęcie przestępstwa rozboju dla sądu kościelnego jest takie, jakim w danym wypadku posługuje się sędzia państwowy.

\subsection{Kodeks Prawa Kanonicznego z 1983 r.}

KPK/1983 wprost nic nie mówi na temat przestępstwa rozboju. $\mathrm{Z}$ tej racji należy uwzględnić tu zasadę ogólną wyrażoną w kan. 13998, która nadaje karny charakter wszystkim kościelnym ustawom, pozbawionym własnej sankcji karnej, których przekroczenie może okazać się szczególnie ciężkie i spowodować zgorszenie.

Przepis kan. 1399 nawiązuje do zasady wyrażonej w kan. 1321 §1-2 KPK/1983, która mówi, że odpowiedzialności karnej w Kościele podlega jedynie ten, kto przekroczył ustawę karną zawartą w Kodeksie lub inną ustawę tego rodzaju, należącą bądź do prawa powszechnego, bądź do prawa partykularnego albo nakaz karny ${ }^{9}$. Ustawodawca w KPK/1983 nie podaje ustawowej definicji przestępstwa, jednak wzorując się na KPK/1917 pod pojęciem przestępstwa rozumie zewnętrzne i moralnie poczytalne przekroczenie ustawy, do której uprzednio dołączona była sankcja karna. Takie określenie przestępstwa jest realizacją zasady legalizmu, którą ujmuje paremia: nullum crimen, nulla poena sine lege poenali praevia tzn., że nie ma przestępstwa bez uprzedniego zagrożenia sankcją karną w ustawie ${ }^{10}$.

Z zasadą wyrażoną w kan. 1399 koresponduje reguła prawa w myśl, której dopuszczalna jest karalność za przekroczenie ustaw, chociaż

${ }^{8}$ Kan. 1399: „Poza wypadkami przewidzianymi w tej lub w innych ustawach, zewnętrzne naruszenie prawa Bożego lub kanonicznego, tylko wtedy może być ukarane sprawiedliwą karą, gdy domaga się tego szczególna ciężkość przekroczenia i przynagla konieczność zapobieżenia zgorszeniom lub ich naprawienia”.

9 J. SyryjCzyK, Kanoniczne prawo karne. Część szczególna, Warszawa 2003, S. 181 .

${ }^{10}$ J. SyryjCzyK, Pojęcie przestepstwa w świetle Kodeksu Prawa Kanonicznego Jana Pawła II, Prawo Kanoniczne 28(1985) nr 1-2, s. 85. 
zwyczajnie nie grozi za ich naruszenie sankcja karna. Zgodnie z kan. 1401 n. $2^{11}$, Kościół z racji grzechu (ratione peccati) jest kompetentny do rozpatrzenia czynu własnym i wyłącznym prawem w tym, co dotyczy stwierdzenia winy i wymiaru kary kościelnej ${ }^{12}$.

Ustanowienie ogólnej sankcji karnej jest zrozumiałe gdyż, ustawodawca kościelny nie jest w stanie sporządzić wyczerpującego katalogu przestępstw i wówczas część czynów niebezpiecznych społecznie uchodziłaby bezkarnie. Takiemu niebezpieczeństwu zapobiega kan. 1399 zgodnie, z którym sprawiedliwą karą można ukarać sprawcę, jeśli domaga się tego szczególna ciężkość przekroczenia i nagli konieczność zapobieżenia lub naprawienia zgorszeń ${ }^{13}$. Wymagana jest, zatem okoliczność obciążająca poczytalność sprawcy, może nią być np. powaga ustawy ze względu na jej przedmiot, czy też wyjątkowo zła wola przekraczającego ustawę. Z kolei jeśli chodzi o drugi czynnik czyli konieczność zapobieżenia przewidywanym zgorszeniom lub naprawienia zgorszeń już wynikłych, to należy zauważyć, że mamy tu do czynienia z liczbą mnogą (w przepisie kan. 1399 jest mowa o zgorszeniach), co wskazuje, iż chodzi tu o zgorszenie o szerszym zasięgu. Zatem postępowanie sprawcy musi wywierać zły wpływ na innych oraz wywoływać - bądź wywołać w przyszłości - oburzenie moralne wśród znacznej części społeczeństwa, w którym się ów sprawca obraca ${ }^{14}$. Niewątpliwie przestępstwo rozboju spełnia obie te przesłanki. Jest to ciężkie przekroczenie prawa oraz wywołuje zgorszenie wśród ludzi.

Zgodnie z prawem Bożym, przestępstwo rozboju jest grzechem ciężkim, gdyż narusza przykazanie Dekalogu: nie kradnij ${ }^{15}$ oraz polega

${ }^{11}$ Kan. 1401 n. 2: „Mocą własnego i wyłącznego prawa, Kościół rozpoznaje przekroczenie ustaw kościelnych oraz wszystkie inne, w których wchodzi w grę grzech, w tym, co dotyczy ustalenia winy i wymierzenia kar kościelnych”.

${ }^{12}$ M. Myrcha, Problem grzechu w karnym ustawodawstwie kanonicznym, Prawo Kanoniczne 29(1986) nr 1-2, s. 75-77.

${ }^{13}$ KPK/1983, kan. 1399.

${ }^{14}$ T. Pawluk, Prawo kanoniczne wedtug Kodeksu Jana Pawła II, t. IV, Olsztyn 1990, s. 155.

${ }^{15}$ Wj 20, 15; Pwt 5,19: „Nie będziesz kradł”. 
na bezprawnym użyciu siły sprzecznym z prawem naturalnym przeciwko drugiemu człowiekowi.

Grzechy należy oceniać według ich ciężaru. Zaś materię ciężkości uściśla dziesięć przykazań. Siódme przykazanie zabrania zabierania lub zatrzymywania niesłusznie dobra bliźniego i wyrządzania mu krzywdy w jakikolwiek sposób dotyczącej jego dóbr ${ }^{16}$. Siódme przykazanie Boże zabrania kradzieży, która polega na przywłaszczeniu dobra drugiego człowieka wbrew racjonalnej woli właściciela. Możemy jednak odnieść zakaz wynikający z tego przykazania, również do rozboju.

Podsumowując należy podkreślić, że do przyjęcia karalności w Kościele bezwzględnie jest konieczne, aby czyn stanowił grzech ciężki, czyli aby z moralnego punktu widzenia był czynem złym. Natomiast ze społecznego punktu widzenia powinien to być grzech ciężki, który zasługuje na oskarżenie i ukaranie z uwagi na powstałą szkodę społeczną ${ }^{17}$.

\section{Strona obiektywna przestępstwa rozboju}

Strona obiektywna przestępstwa rozboju, to inaczej strona przedmiotowa. Należy zwrócić tu uwagę, na ustawowe znamiona przestępstwa rozboju i na przedmioty ochrony karnej. Przy dokonywaniu przestępstwa sprawca zachowuje się w określony sposób (np. zabiera określoną rzecz), posługuje się przy tym różnymi środkami i narzędziami, działa w konkretnych okolicznościach, w określonym czasie, miejscu i sytuacji.

\subsection{Kodeks Prawa Kanonicznego z 1917 r.}

W kanonicznym prawie karnym przez rozbój rozumie się niesprawiedliwy zabór cudzej rzeczy, dokonany przy użyciu siły.

KPK/1917 ustanawiając sankcję karną za przestępstwo rozboju (kan. 2354 §1-2), zwraca uwagę, że przedmiotem nieprawego zaboru kwalifikującego się pod miano tegoż bezprawia jest mienie (res).

\footnotetext{
${ }^{16}$ Katechizm Kościoła Katolickiego, Pallottinum - Poznań 1994, nr 1854-1860, 2401.

${ }^{17}$ J. SyryjczyK, Kanoniczne prawo karne, s. 182; Por. M. Myrcha, Problem grzechu w karnym ustawodawstwie kanonicznym, s. 76-77.
} 
Przedmiotem rozboju według KPK/1917 jest każde mienie, bez względu na jego wartość.

Prawodawca w kan. $1933 \S 3$ KPK/1917 postanawia, że świeccy odnośnie do przestępstw forum mieszanego, a takim przestępstwem jest rozbój, w zasadzie winni być pozostawieni stosownemu ukaraniu władzy świeckiej $^{18} . Z$ tego względu, w prawie kanonicznym stronę przedmiotową przestępstwa rozboju stanowić będą rozwiązania przyjęte w państwowych kodeksach karnych, a w naszym przypadku w prawie karnym polskim.

W początkowym okresie rozwoju kościelnego prawa karnego legalny element przestępstwa nie był bezwzględnie wymagany, tzn. nie stanowił koniecznego elementu przestępstwa. $\mathrm{W}$ praktyce przełożeni kościelni wymierzali kary za czyny moralnie złe nie tylko z racji grzechu ciężkiego, lecz także ze względu na zakłócenie porządku publicznego na forum zewnętrznym. Zasada legalizmu sformułowana w okresie oświecenia stanowi, że warunkiem karalności jakiegoś czynu społecznie szkodliwego jest uprzednie zagrożenie sankcją karną w ustawie ${ }^{19}$. Reguta Nulla poena sine lege poenali praevia - zakazuje wymierzać sprawcy karę za przypisane mu przestępstwo, jeśli nie jest ona w ustawodawstwie karnym uprzednio przewidziana. Zasada legalności nie jest postulatem prawa naturalnego, czyli wymogiem bezwzględnym, ale prawa czysto pozytywnego. Wymogiem bezwzględnym prawa naturalnego jest wina. Według prawa naturalnego władza publiczna może karać czyny ciężko zawinione i naruszające porządek społeczny. Nie jest konieczne natomiast wcześniejsze obwarowanie ich sankcją karną ${ }^{20}$.

Podsumowując trzeba zaznaczyć, że prawodawca w KPK/1917 w kwestii przestępstwa rozboju kieruje się jego rozumieniem tak, jak jest ono ujmowane w systemie państwowym. Nie posługuje się innym, ponieważ chce uniknąć dwutorowości, czyli odrębnego jego rozumienia w państwie, od ujmowania go przez Kościół.

${ }^{18}$ Kan. 1933 §3: „In delictis mixti fori Ordinarii regulater ne procedant cum reus laicus est et civilis magistratus, in reum animadvertens publico bono satis consulit".

${ }^{19}$ J. KruKowsKi, Problem rewizji kan. 2222 Kodeksu Prawa Kanonicznego, Roczniki Teologiczno - Kanoniczne 17(1970) z. 5, s. 46.

${ }^{20}$ A. PrzybyŁa, Zasada legalności w kościelnym prawie karnym, Prawo Kanoniczne 14(1971) nr 1-2, s. 226, 228-229. 


\subsection{Kodeks Prawa Kanonicznego z 1983 r.}

KPK/1983, w porównaniu z KPK/1917, znacznie zredukował przestępstwa mixti fori, w których ściganiu zainteresowana jest zarówno władza państwowa, jak i kościelna. Powodem takiego rozwiązania jest fakt, że przestępstwa te w sposób dostateczny i wystarczający ścigane i karane są przez władzę państwową. Oprócz tego Kościół respektując zasadę prawa naturalnego ujętą $\mathrm{w}$ paremii ne bis idem, obawia się, aby sprawca przestępstwa, które narusza dobro wspólnoty kościelnej będące zarazem dobrem społeczności państwowej nie był dwukrotnie karany za ten sam czyn społecznie szkodliwy.

Biorąc pod uwagę fakt, iż rozbój narusza prawo Boże, a więc jest grzechem ciężkim, Kościół nie może zrzec się całkowicie swojej kompetencji w stosunku do tegoż bezprawia.

Jak już wcześniej powiedziano w wypadku gdy sprawca dopuścił się przestępstwa rozboju, a nie został ukarany przez władzę świecką lub został niewystarczająco ukarany, w oparciu o kan. 1399 KPK/1983, może być pociągnięty do odpowiedzialności karnej gdy spełnione są warunki, a sędzia kościelny rozważając stronę przedmiotową czynu winien posłużyć się ujęciem tego zagadnienia jakie jest przewidziane w prawie karnym polskim. W myśl kan. 1399, do odpowiedzialności karnej wystarczy, że ukarania domaga się szczególna ciężkość wykroczenia i przynagla konieczność zapobieżenia lub naprawienia zgorszeń, chociażby wykroczenie nie było wcześniej obwarowane sankcją karną. W związku z tym do przyjęcia karalności w Kościele bezwzględnie jest konieczne, aby czyn z moralnego punktu widzenia był czynem złym - stanowiącym grzech ciężki. Natomiast ze społecznego punktu widzenia, aby był grzechem zasługującym na oskarżenie i ukaranie - ze względu na powstałą szkodę społeczną ${ }^{21}$.

${ }^{21}$ Th. J. Green, Book VI: Sanctions in the Church (cc. 1311-1399), w: The Code of Canon Law. A text and commentary, ed. J. Coriden - Th. Green - D. E. Heintschel, New York 1985, s. 930; J. SyryjczyK, Kanoniczne prawo karne, s. 182; V. DE Paolis, De sanctionibus in Ecclesia. Adnotationes in Codicem: Liber VI, Romae 1986, s. 122 123. 
Kan. 1399 zawiera sankcję kanoniczną nieokreśloną za wszystkie czyny szczególnie karygodne i wywołujące zgorszenie ${ }^{22}$. Zasada nie może wywoływać wrażenia jakoby w Kościele zachodziło zjawisko penalizacji wszystkich norm prawa Bożego i kanonicznego ${ }^{23}$. Karalność przekroczenia ustaw nie opatrzonych sankcją karną, jest bowiem wyjątkowa i obwarowana wspomnianymi wyżej warunkami.

Należy podkreślić, że wielkość przestępstwa z przedmiotowego punktu widzenia mierzy się rodzajem dobra naruszonego przez sprawcę, a więc szkodliwością społeczną czynu. Chodzi zatem o walor pogwałconej ustawy ze względu na jej przedmiot. Oceniając wielkość przestępstwa, trzeba również uwzględnić szkodę osoby dotkniętej przestępstwem (damnum immediatum) oraz szkodę, jaką pośrednio ponosi wspólnota kościelna, czyli szkodę społeczną, która wynika z deliktu (damnum mediatum).

Drugim warunkiem zastosowania ogólnej normy karnej jest nagląca konieczność naprawienia powstałych już zgorszeń albo zapobieżenia zgorszeniom mogącym powstać, czyli przewidywanym ${ }^{24}$.

Reasumując należy przyjąć, iż sędzia kościelny w kwestii dotyczącej strony przedmiotowej przestępstwa rozboju winien sięgnąć po rozstrzygnięcia, jakie są przewidziane w prawie karnym polskim. Za przyjęciem takiego stanowiska przemawiają następujące racje: po pierwsze - brak wyraźnego przepisu regulującego przestępstwo rozboju w prawie kanonicznym; po drugie - Kościół dąży do tego, aby uniknąć zbytniej arbitralności sądów kościelnych; po trzecie - odmienne rozumienie strony przedmiotowej czynu w państwie a odmienne w Kościele. Dzięki takiemu rozwiązaniu, Kościół zapobiega, aby sprawca przestępstwa nie został dwukrotnie ukarany za ten sam czyn społecznie szkodliwy.

${ }^{22}$ J. SyryjCZyK, Kanoniczne prawo karne, s. 183.

${ }^{23}$ J. Krukowski, Księga VI. Sankcje w Kościele, w: Komentarz do Kodeksu Prawa Kanonicznego z 1983 r., T. 4, Lublin 1987, s. 126-127.

${ }^{24}$ J. SyryjczyK, Kanoniczne prawo karne, s. 184-185; V. De Paolis - D. Cito, Le sanzioni nella Chiesa. Commento al Codice di Diritto Canonico. Libro VI, Roma 2000, s. 368-369. 


\section{Strona subiektywna przestępstwa rozboju}

\subsection{Kodeks Prawa Kanonicznego z 1917 r.}

Przestępstwo rozboju należy do przestępstw kierunkowych, które w świetle norm kodeksowych można popełnić tylko z winą umyślną, czyli działając w złym zamiarze. Określenie winy umyślnej podaje kan. $2200 \S 1 \mathrm{KPK} / 1917^{25}$. Z przepisu tego wynika, że do poczytania przestępstwa $\mathrm{z}$ winy umyślnej konieczna jest znajomość normy prawnej, ku której skierowane jest działanie lub zaniechanie sprawcy oraz jego wolność zarówno w dziedzinie wyboru, jak i w sferze działania ${ }^{26}$.

Świadomość sprawcy przekraczającego normę prawną winna obejmować nie tylko przekraczaną ustawę, ale również wyobrażenie o czynie, który odpowiada wszystkim cechom przekraczanego przepisu. Ponadto sprawca musi mieć świadomość, że pomiędzy jego działaniem a wywołanym skutkiem zachodzi związek przyczynowy natury fizycznej i psychicznej ${ }^{27}$. Elementy świadomości i woli w myśl kan. 2200 §1 muszą wystąpić łącznie. Przestępna wola, aby miała znamiona umyślności musi pochodzić z uprzedniego poznania. $Z$ tej racji koniecznym warunkiem zaistnienia winy umyślnej w konkretnym przestępstwie jest zamiar popełnienia czynu zabronionego przez prawo karne. Innymi słowy, aby działać w złym zamiarze świadomość musi obejmować bezprawność czynu ${ }^{28}$.

Rodzi się pytanie, czy do dokonania przestępstwa rozboju wystarczy jedynie świadomość bezprawności, czy konieczna jest również świadomość przestępczości czynu.

${ }^{25}$ Kan. 2200 §1: Dolus heic est deliberata voluntas violandi legem.

${ }^{26}$ M. MYrcha, Problem winy w karnym ustawodawstwie kanonicznym, s. 166; Tenże, Prawo karne. Komentarz do piątej księgi Kodeksu Prawa Kanonicznego, t. II, Kara, cz. I, Przepisy ogólne, Warszawa 1960, s. 275, 355, 356; F. RoBerTI, De delictis et poenis, vol. I, pars I, Romae 1930, s. 53-55.

${ }^{27}$ F. Roberti, jw., s. 89, 90; M. Myrcha, Problem winy..., s. 167.

${ }^{28}$ M. Myrcha, Problem winy..., s. 169; G. Michiels, De delictis et poenis. Commentarius libri V Codicis Iuris Canonici, vol. I, De delictis, Parisiis - Tornaci - Romae - Neo Eboraci 1961, 111. 
Prawodawca w kan. $2202 \S 2 \mathrm{KPK} / 1917^{29}$ ustala zasadę, iż ignorancja przestępczości nie znosi przestępstwa, lecz do jego dokonania wystarczy sama świadomość bezprawności czynu.

W myśl przepisów KPK/1917 do zaistnienia przestępstwa rozboju koniecznym warunkiem jest świadomość sprawcy o bezprawności jego czynu, natomiast niekonieczna jest świadomość przestępczości, czyli niekonieczna jest znajomość grożącej sankcji karnej za popełnione przestępstwo rozboju ${ }^{30}$.

Przestępstwa kierunkowe charakteryzują się określonym celem, do którego sprawca zmierza. Jeśli sprawca działa w pewnym celu, to przestępstwo czy skutek przestępny, nie mogą pozostawać dla niego niepożądane lub obojętne ${ }^{31}$. Rozbój jest przestępstwem kierunkowym, które może być popełnione wyłącznie z zamiarem specjalnym (dolus specificus), a więc wykluczona jest tu wina nieumyślna.

\subsection{Kodeks Prawa Kanonicznego z 1983 r.}

Zgodnie z kan. 1321 §1 źródłem kryminalnego poczytania czynu przestępnego jest wina umyślna lub wina nieumyślna ${ }^{32}$. W zasadzie jednak odpowiedzialność karna została ograniczona do winy umyślnej, bowiem tylko wyjątkowo dopuszczalna jest karalność za winę nieumyślną. W myśl kan. 1321 § KPK/1983 przestępstwa nieumyślne $\mathrm{z}$ reguły są niekaralne, jedynie wyjątkowo podlegają one odpowiedzialności karnej, gdy karalność ich przewidziana jest wyraźnie w ustawie karnej. Kan. 1399 KPK/1983 nie przewiduje takiego wyjątku. Z tej racji naruszenie prawa Bożego lub kanonicznego, które

${ }^{29}$ Kan. $2202 \S 1$ : „Ignorantia solius ponae imputabilitatem delicti non tollit, sed aliquatum minuit".

${ }^{30}$ M. Myrcha, Problem winy..., s. 170-172: Wyjątkiem są przestępstwa, za które grozi kara poprawcza: „do popełnienia przestępstwa umyślnego, za które przewidziana jest kara poprawcza (cenzura), konieczna jest po stronie sprawcy świadomość nie tylko bezprawności, ale także i przestępczości”.

${ }^{31}$ Tamże, s. 190.

${ }^{32}$ Kan. 1321 §1: „Nie można nikogo karać, jeśli popełnione przez niego zewnętrzne naruszenie ustawy lub nakazu nie jest ciężko poczytalne na skutek winy umyślnej lub nieumyślnej". 
uprzednio nie zostało zagrożone sankcją karną, w warunkach tegoż kanonu, może być karane tylko wtedy, gdy przestępstwo zostało dokonane $\mathrm{z}$ winą umyślną ${ }^{33}$.

Między KPK/1917 i KPK/1983 zachodzi zgodność, tzn. przyjmują one, że przestępstwo rozboju zalicza się do przestępstw kierunkowych i można je popełnić z winy umyślnej w postaci zamiaru bezpośredniego, zaś wykluczona jest wina nieumyślna.

\section{Sankcja karna}

\subsection{Kodeks Prawa Kanonicznego z 1917 r.}

4.1.1. Karalność rozboju dokonanego przez osoby świeckie

Prawodawca kościelny w kan. 2354 §1-2 KPK/1917, przewiduje odmienną sankcję karną za przestępstwo rozboju popełnione przez osoby duchowne od zagrożenia karnego dla świeckich. Kodeks przewiduje, że osoba świecka za powyższe bezprawie kryminalne zostanie ukarana przez sąd świecki: Laicus qui fuerit legitime damnatus ob delictum(...) rapinae. Oprócz odpowiedzialności karnej przewidzianej w kan. 2354 §1 KPK/1917 sprawca rozboju popada w karę latae sententiae wyłączającą go od prawnych aktów kościelnych i jakiegokolwiek urzędu piastowanego w Kościele. Ponadto prawodawca nakłada obowiązek naprawienia powstałej szkody: (...) ipso iure exclusus habeatur ab actibus legitimis ecclesiaaticis et a quolibet munere, si quod in Ecclesia habeat, firmo onere reparandi damna (kan. $2354 \S 1)^{34}$.

Co należy rozumieć przez kościelne akty prawne, określa kan. 2256 n. 2. Według postanowienia tego kanonu kościelnymi aktami prawnymi są: sprawowanie zarządcy majątku kościelnego, czynności sędziego, audytora, instruktora, obrońcy węzła, promotora sprawiedliwości wiary,

${ }^{33}$ L. Chiappetta, Il Codice di Diritto Canonico. Commento giuridico - pastorale, II, Roma 1996, s. 597, 692; J. SyryJCZyK, Kanoniczne prawo karne, s. 184-185; J. SyryJCZYK, Pojęcie przestęstwa w świetle Kodeksu Prawa Kanonicznego Jana Pawła II, s. 92-94.

${ }^{34}$ J. SyRYJCZYK, Kradzież w karnym prawie kanonicznym i polskim, msp. Biblioteka UKSW, Warszawa 1979, s. 243. 
notariusza i kanclerza, woźnego i komornika, adwokata i prokuratora w sprawach kościelnych; funkcje ojca chrzestnego lub świadka bierzmowania; czynność i bierność, głosowanie przy wyborach kościelnych, wykonywanie prawa patronatu.

Oprócz tego sprawca rozboju pozbawiony jest ipso facto wszelkich urzędów, które sprawował w Kościele (a quolibet munere). Zajęciami albo urzędami dla świeckich w Kościele przewidzianymi przykładowo w kan. 1185 KPK/1917 są: zakrystianin, śpiewak, organista, dzwonnik, grabarz itp. Urzędami przewidzianymi przez prawodawcę kościelnego dla świeckich w Motu proprio „Causas Matrimoniales” są: urząd sędziego w trybunale kolegialnym dla rozpatrzenia i rozstrzygnięcia ważności małżeństwa, funkcja asesora i audytora. Ponadto urząd notariusza w sądzie kościelnym mogą pełnić nie tylko świeccy mężczyźni, ale i kobiety ${ }^{35}$.

Zgodnie z kan. 1933 §3 KPK/1917, jeśli osoba świecka dopuści się przestępstwa forum mieszanego, prawodawca uznaje wyrok władzy świeckiej ${ }^{36}$. Przez ten fakt nie rezygnuje jednak z utrzymania tych przestępstw jako kanonicznych, nawet w stosunku do świeckich. Potwierdzeniem takiego wniosku jest norma kan. 2354 §1 KPK/1917, gdzie obok kar ferendae sententiae za przestępstwo rozboju wymierzonych przez trybunał państwowy, prawodawca grozi karą latae sentenitae. Takie unormowanie zagrażać może nieproporcjonalnością ciężkości deliktu z ciężarem kary. W ten sposób, że kara stałaby się bardziej dolegliwa niż wyrządzone bezprawie oraz świadczyć by to mogło o dwukrotnym karaniu tego samego przestępstwa.

Zdaniem Coronaty w wypadku, gdy sprawca rozboju zostanie uwolniony od kary przez trybunał świecki, tym samym nie zaciąga on kary latae sententiae kan. $2354 \S 1$ KPK $/ 1917^{37}$. Coronata błędnie

${ }^{35}$ Paulus VI, Motu proprio „Causas matrimoniales”, n. V, §1, n. VI; AAS 63 (1971), s. 441-446.

${ }^{36}$ Kan. 1933 §3: „In delictis mixti fori Ordinarii regulariter ne procedant cum reus laicus est et civilis magistratus, in reum animadvertens, publico bono satis consuli".

${ }^{37}$ M. C. A. Coronata, Institutiones iuris canonici, vol. IV, De delictis et poenis, ed. IV, aucta et emendata, Taurini - Romae 1955, s. 519; podobnie zagadienie to ujmuje R. SALucCI, II dritto penale secondo il Codice di dritto canonico, Subiaco 1926, t. II, n. 269. 
twierdzi, że zaciągnięcie kary latae sententiae jest uzależnione od wyroku skazującego sądów świeckich. Właściwością kar latae sententiae jest, że zaciąga się je z chwilą popełnienia przestępstwa i niezależnie od skazania przez sąd świecki ${ }^{38}$.

4.1.2. Sankcje karne przeciwko duchownym dopuszczającym się przestępstwa rozboju

W stosunku do duchownych za popełnione przestępstwo rozboju prawodawca w kan. 2354 §2 KPK/1917 ${ }^{39}$ przewiduje szereg kar, które mogą być wymierzone w zależności od ciężaru zawinienia sprawcy (pro diversa reatus gravitate) $^{40}$. Kary przewidziane w kan. $2354 \S 2$ dla duchownych są karami ferendae sententiae. Prawodawca zgodnie z normą kan. $120 \S 1$ stanowi, że duchowni we wszystkich sprawach spornych natury cywilnej lub karnej winni być pozwani przez sędziego kościelnego ${ }^{41}$. Kościół dąży, więc do utrzymania privilegium fori $\mathrm{w}$ stosunku do duchownych. Za przestępstwo rozboju popełnione przez duchownych grozi pokutami i cenzurami, a więc zgodnie z kan. $2255 \S 1 \mathrm{KPK} / 1917$ : ekskomuniką, interdyktem lub suspensą, ponadto karami odwetowymi, a mianowicie pozbawieniem urzędu, beneficjum lub godności, a w razie potrzeby nawet karą depozycji (kan. $2354 \S 2$ KPK/1917).

Różnego rodzaju i ciężkości kary przewidziane w kan. 2354 §2 są wynikiem nie tylko różnego rodzaju przestępstw przewidzianych w $§ 1$ tegoż kanonu, ale również ciężkością popełnionego przestępstwa, w tym także rozboju.

\footnotetext{
${ }^{38}$ M. Myrcha, Prawo karne..., t. II, s. 273.

${ }^{39}$ Kan. 2354 §2: „Clericus vero qui aliquod delictum commiserit de quibus in $\S 1$, a tribunali ecclesiastico puniatur, pro diversa reatus gravitate, poenitentiis, censuris, privatione officii ac beneficii, dignitatis, et, si res ferat, etiam depositione; reus vero homicidii culpabilis degradetur'.

${ }^{40}$ F. Bączkowicz, Prawo kanoniczne. Podręcznik dla duchowieństwa, t. III, wyd. 3, uzupełnili: J. Baron - W. Stawinoga, Opole 1958, s. 539.

${ }^{41}$ Kan. 120 §1: „Clerici in omnibus causis sive contentiosis sive criminalibus apud iudicem ecclesiasticum conveniti debent, nisi aliter pro locis particularibus legitime provisum fuerit"; Por. F. Cappello, Summa iuris canonici, vol. III, De processibus, delictis et poenis, ed. 3, emendata et aucta, Romae 1948, s. 541.
} 
Zaistnieć może sytuacja, że sprawca rozboju jako osoba duchowna zostanie ukarany przez trybunał świecki. Inaczej mówiąc, kiedy władza państwowa nie uzna privilegium fori. Wymierzenie wówczas szczególnie ciężkiej kary przez sędziego kościelnego przeczyłoby zasadzie ne bis in idem tym bardziej, gdy kara nałożona przez sąd świecki w dostateczny sposób może spełnić cele, ku którym zmierza wymiar kar kościelnych tak, że nie wydaje się potrzebne lub konieczne karanie sprawcy przez Kościół ${ }^{42}$.

Zgodnie z kan. 2210 §1 n. 2 oraz postanowieniem kan. $2354 \S 2$ KPK/1917 sprawca rozboju zobowiązany jest do naprawienia szkody powstałej w wyniku popełnionego bezprawia (reparandi damna). Zauważyć należy, że pojęcie naprawienia szkody jest zakresowo szersze niż restytucja samego przedmiotu rozboju. W wyniku rozboju poszkodowany traci $\mathrm{w}$ związku $\mathrm{z}$ mieniem to wszystko, co mogło ono przysporzyć oraz to, co z jego utratą musiał wydać. Z tego względu naprawienie szkody, w wyniku powstałego rozboju obejmuje restytucję przedmiotu rozboju oraz wszelkie straty powstałe w wyniku rozboju po stronie posiadającego dane mienie ${ }^{43}$.

Według Coronaty obowiązek naprawienia szkody wynika z zasad moralnych i nie ma charakteru karnego ${ }^{44}$. Natomiast w myśl normy kan. $2210 \S 1$ n. $2^{45}$ naprawienie szkody powinno się rozumieć jako obowiązek prawa cywilnego. Obowiązek etyczny, gdy jest poparty prawem staje się obowiązkiem prawnym. Odnosi się do szkody prywatnej. Sprawca rozboju zobowiązany jest do naprawienia zgorszenia, przywrócenia naruszonego porządku społecznego oraz zabezpieczenia innych przed popełnieniem przestępstwa ${ }^{46}$.

${ }^{42}$ M. Mrrcha, Prawo karne..., t. II, cz. I, s. 419-424.

${ }^{43}$ J. SyRYjCZYK, Kradzież w karnym prawie kanonicznym i polskim, s. 246.

${ }^{44}$ M. C. A. Coronata, Institutiones iuris canonici, vol. IV, s. 519.

${ }^{45}$ Kan. $2210 \S 1$ n. 2: „Ex delicto oritur: Actio civilis ad reparanda damna, si cui delictum damnum intulerit".

${ }^{46}$ M. Myrcha, Prawo karne..., t. II, s. 344, 345. 


\subsection{Kodeks Prawa Kanonicznego z 1983 r.}

Norma ogólna wyrażona w kan. 1399 KPK/1983, zawiera sankcję karną o charakterze ogólnym, która grozi sprawcy, jeśli dopuścił się on przekroczenia prawa Bożego albo kościelnych ustaw powszechnych lub partykularnych, gdy jest ono szczególnie ciężkie i powoduje lub może spowodować zgorszenia. Dzięki temu wszystkie ustawy kościelne otrzymują charakter karny, jeżeli w danej sytuacji zostaną spełnione jednocześnie obydwa wymienione wyżej warunki ${ }^{47}$. Warto w tym miejscu zwrócić uwagę, na przewidzianą w kan. 1344 n. 2 KPK/1983 możliwość odstąpienia od ukarania sprawcy, jeśli przypuszcza się, że zostanie on dostatecznie ukarany przez władzę świecką bądź już został ukarany. Wydaje się, iż sędzia kościelny korzystając z tej normy, powstrzyma się od wymierzenia kary sprawcy rozboju, bowiem polskie prawo karne przewiduje stosunkowo surowe kary za popełnienie przestępstwa rozboju. Ukaranie jednak sprawcy rozboju przez władzę świecką nie gasi prawa karania przez władzę kościelną.

Za naruszenie ustaw pozakarnych przewidziana jest karalność fakultatywna, a sankcja karna nieokreślona. Ocenie sędziego podlega decyzja o karalności sprawcy. Sędzia zgodnie z własnym sumieniem i roztropnością wymierza karę, określając jej rodzaj i wielkość. Sędzia wymierzając karę, gdy sankcja karna w ustawie jest nieokreślona, musi mieć na uwadze reguły przewidziane w kan. 1349 KPK/1983 ${ }^{48}$.

Zgodnie z powyższym kanonem, jeśli sankcja karna przewidziana w ustawie jest nieokreślona, wówczas sędzia nie powinien wymierzać kar ciężkich, do których zawsze zaliczane są cenzury, czyli kary poprawcze, które traktuje się jako kary szczególnie dotkliwe ze względu na ich skutki. Wprawdzie prawodawca radzi sędziemu, aby w takiej sytuacji nie wymierzał on ciężkich kar, chociaż mu tego nie zabrania.

${ }^{47}$ J. SyryjczyK, Kanoniczne prawo karne, s. 185; TH. J. GreEn, Book VI: Sanctions in the Church (cc. 1311-1399), s. 930-931.

${ }^{48}$ Kan. 1349: „Jeśli kara jest nieokreślona, a ustawa czego innego nie zastrzega, sędzia nie powinien wymierzać cięższych kar, zwłaszcza cenzur, chyba że domaga się tego bezwzględnie ciężkość przypadku; kar zaś wiążących na stałe nie może wymierzać". 
Jednakże przepis ten należy uznać za drogowskaz dany sędziemu, gdy sankcja karna jest nieokreślona, co zostało wzmocnione barierą absolutnego zakazu wymierzania kar dożywotnich.

Prawodawca w KPK/1983 za przestępstwo rozboju przewiduje karalność fakultatywną, odmiennie niż w KPK/1917, który przewidywał karalność obligatoryjną. Sankcja karna w KPK/1983 jest arbitralna to znaczy, że roztropności i sumieniu sędziego pozostawiony jest wybór rodzaju kary i określenie jej wysokości. Natomiast w KPK/1917 sankcja karna za powyższe bezprawie kryminalne była ściśle określona w stosunku do laików, zaś odnośnie do duchownych sankcja karna była proporcjonalna $\mathrm{w}$ zależności od ciężaru popełnionego przestępstwa (przewidziane były: pokuty, cenzury, pozbawienie urzędu, beneficjum lub godności i jeżeli sprawa tego wymagała także kara depozycji).

\section{Wnioski końcowe}

W KPK/1983 zrezygnowano, w wielu wypadkach, z zagrożenia karnego za przestępstwa należące do forum mieszanego (mixti fori), w których ściganiu i karaniu zainteresowany jest zarówno Kościół, jak i władza państwowa, czego przykładem jest przestępstwo rozboju. Uwalnia to ustawodawcę kościelnego od wydłużania listy przestępstw w swoim kodeksie karnym, a jednocześnie daje możliwość zagrożenia tego rodzaju czynów sankcją karną w ustawodawstwie partykularnym. Oprócz tego takie rozwiązanie nie prowadzi do sporów kompetencyjnych na styku Kościół - państwo. Ponadto nie ma obawy, że sprawca zostanie dwukrotnie ukarany za to samo przestępstwo, tzn. raz przez państwo i drugi raz przez Kościół, co naruszałoby zasadę prawa naturalnego, która głosi ne bis idem ${ }^{49}$.

Już w Schemacie nowego kanonicznego prawa karnego z 1973 roku, wydanym przez Papieską Komisję Kodyfikacyjną przyjęto założenie, w myśl którego w nowym Kodeksie Prawa Kanonicznego zostanie w poważnym stopniu zmniejszona liczba kanonów dotycząca przestępstw w szczególności. W Projekcie z 1973 r. zaproponowano,

${ }^{49}$ J. SyRYJCZYK, Kanoniczne prawo karne, s. 13-14. 
aby większa ich część umieszczona została w ustawodawstwie partykularnym ${ }^{50}$.

Z punktu widzenia trybu ścigania przestępstwa rozboju KPK/1917 i KPK/1983 zaliczają je do przestępstw publiczno - skargowych.

\section{Banditry as seen in criminal canonical law}

The article touches upon the crime of banditry as seen in criminal canonical law. It depicts the way in which the crime of banditry was presented in the Code of Canonical Law both of 1917 and of 1983 . The crime of banditry is committed by a person who steals another person's property while resorting to or threatening to resort to violence or while bringing a person to the state of unconsciousness or defenselessness. Banditry falls within intentional crimes intended to take another person's property willfully in order to misappropriate it.

The crime of banditry has always been treated as one of the heaviest crimes against property. In terms of its burden, the way the crime was committed is decisive, among others. Frequently this attack ends up in taking life of an assaulted person or in a serious damage to his or her body.

In criminal canonical law the crime of banditry falls within mixti fori crimes which means that the perpetrator may be pursued and punished both by church and national authorities. The canonical judge while respecting the principle of natural law which says ne bis idem, is forced to take into account national criminal laws in his proceedings. Such reasoning is justified by CIC/1917 can. 2198, can. 1933 §3, can. $2223 \S 3$ n. 2 and can. $2354 \S 1-2$ and in CIC/1983 particularly can. 1344 n. 2 and can. 1399.

${ }^{50}$ Pontificia Commissio Codici Iuris Canonici Recognoscendo, Schema documenti quo disciplina sanctionum seu poenarum in Ecclesia Latina denuo ordinatur, Typis Polyglottis Vaticanis 1973, s. 5. 